\title{
Note
}

\section{Disabling Corrections and Correctable Disabilities: Why Side Effects Might Be the} Saving Grace of Sutton

\author{
Lauren J. McGarity
}

On June 22, 1999, Maine attorney Peter Thompson reluctantly called two of his clients to inform them that he was dropping their employment discrimination cases. ${ }^{1}$ Thompson bluntly explained to his two diabetic clients that the Supreme Court had just declared that diabetics and other individuals with "correctable" impairments were not individuals with disabilities, and thus not entitled to the protections of the Americans with Disabilities Act (ADA). As word of the surprising ruling spread, many attorneys across the nation were no doubt inclined to follow in Thompson's footsteps. However, Thompson and his colleagues may have picked up the phone too soon. Though the Court's recent decisions in the correctable disabilities cases have been a magnet for controversy, the spirited debate over their normative implications has displaced careful analysis of their practical legal effects. Closer examination of the language of these opinions reveals that, despite the advocacy community's understandably panicked reaction to these decisions, the impact of the Supreme Court's holding on the scope of the ADA's protections may be significantly narrower than initial interpretations would indicate.

In Sutton v. United Air Lines, ${ }^{2}$ Albertsons, Inc. v. Kirkingburg, ${ }^{3}$ and Murphy v. United Parcel Service, ${ }^{4}$ the Supreme Court rejected the

1. See Maggie Jackson, Rulings Called "Horrible Casch-22" for Disabled, ATnANTA J.ConsT., June 23, 1999, at Al.

2. 119 S. Ct. 2139 (1999).

3. 119 S. Ct. 2162 (1999).

4. 119 S. Ct. 2133 (1999). 
predominant understanding of what constitutes a disability under the ADA and clarified that, in evaluating whether or not an individual is entitled to the statute's protections, the individual's ability to mitigate or correct his or her impairment must be considered. ${ }^{5}$ Thus, those individuals who use medications or medical devices to correct their impairments (or who are able to compensate for their impairments without the aid of such corrective measures) may not be entitled to the law's protections. Interpretations of the decisions in the popular media reveal a widespread perception that the Supreme Court rendered the ADA powerless in the workplace. ${ }^{6}$ Newspapers reported alarmingly (and inaccurately) that these decisions declared individuals with diabetes, cancer, and amputated limbs to be ineligible for the ADA's protections, ${ }^{7}$ and one plaintiff reportedly felt guilty that his suit would cause courts to "throw cases out" and "cost a lot of people their jobs." 8 Indeed, the first handful of lower-court cases decided under the new Supreme Court precedents seems to confirm the dire predictions that many individuals with disabilities have "lost their best protection against employment discrimination." 9

A closer reading of the majority opinions in the correctable disabilities cases, however, reveals that the majority was keenly aware of the devastating effect that an expansive interpretation of its holdings could have on the ADA's beneficiaries. In an explicit attempt to narrow the impact of the decisions and to clarify the specific nature of its holding, the majority was careful to identify groups of individuals who would still be entitled to the law's protections. ${ }^{10}$ Notably, the Court emphasized in Sutton-the leading case in this series of decisions-that one of the rationales underlying the majority's holding was its belief that viewing disabilities in their "corrected" or "mitigated" state was the only way to permit courts and employers to "consider any negative side effects suffered by an

5. See Sutton, 119 S. Ct. at 2143.

6. See, e.g., Ellen Goodman, A Nearsighted Supreme Court, ORLANDO SENTINEL TRIB., June 29, 1999, at A9 (arguing that the decisions "limited the reach of the Americans with Disabilities Act beyond recognition"); Supreme Mischief, N.Y. TIMES, June 24, 1999, at A26 (characterizing the decisions as "deeply disturbing" and arguing that the decisions "significantly weaken" the ADA's protections, creating a "crabbed version" of the law that ignores its intended purpose).

7. See, e.g., Jan Crawford Greenburg, Ruling Trims the Scope of Disability Law: High Court Excludes Correctable Impairments from Job Protection, CHI. TRIB., June 23, 1999, at I.

8. Lynette Clemetson, A Sharper Image of Bias, NEwSWEEK, July 5, 1999, at 27.

9. A Bad Day at the Court, EPILEPSY USA (Epilepsy Found., Landover, Md.), June-July 1999, at 2, 2; see also infra note 74 (citing initial lower-court decisions).

10. See, e.g., Sutton, $119 \mathrm{~S}$. Ct. at 2149 (clarifying that the Court's decision does not cxclude all individuals who utilize corrective devices, that an individual who uses a prosthetic limb may still be appropriately considered to be an individual with a disability because of a substantial limitation on her ability to walk or run, and that individuals who use imperfect corrections may still meet the definition of a disability); Albertsons, Inc. v. Kirkingburg, $119 \mathrm{~S}$. Ct. 2162, 2169 (1999) (suggesting that most individuals with monocular vision would "ordinarily" meet the Act's definition of disability). 
individual resulting from the use of mitigating measures." "Though the dissent challenged the accuracy of this statement, ${ }^{12}$ the majority's tacit identification of individuals who use "disabling corrections" as a group entitled to the protections of the ADA is significant.

As the next wave of post-Sutton ADA litigation begins to focus on what constitutes a correctable disability, ${ }^{13}$ courts will undoubtedly encounter both (1) plaintiffs who argue that their corrective measures are "imperfect" and (2) plaintiffs who invoke the "disabling corrections" language in Sutton to argue that the side effects of their corrective measures substantially limit a major life activity. ${ }^{14}$ While the former group of plaintiffs is likely to present courts with relatively familiar factual disputes about the precise nature of their individual limitations, courts that encounter disabling corrections claims will face novel legal questions that have the potential to influence significantly the practical impact of the correctable disabilities decisions. Future courts' answers to these questions will determine whether the Sutton ruling truly "cuts the heart out of the $A D A$ " Is or whether the decision merely narrows the Act's applicability in a manner that is consistent with the goals of the statute's authors.

Sutton's "disabling corrections" language encompasses a wide range of potential plaintiffs. Individuals who take medications that cause extreme drowsiness, nausea, or other severe side effects would be appropriately considered "individuals with disabilities" under this language, as would individuals who have had corrective surgeries, such as colostomies or hysterectomies, that give rise to permanently disabling conditions. Arguably, even drugs that are known to cause birth defects would be properly considered disabling corrections for the purposes of the ADA. ${ }^{16}$ If courts conceptualize the disabling correction broadly, this interpretation will partly offset Sutton's constraints on the size of the ADA's protected class. Sutton could then be read to exclude from the ADA's protections only those individuals with conditions that are truly minor and easy to correct, like nearsightedness, and to include most individuals with more serious conditions, such as epilepsy and diabetes, which often require

11. Sutton, 119 S. Ct. at 2147.

12. See id. at 2159 n.5 (Stevens, J., dissenting).

13. See, e.g., Clemetson, supra note 8, at 27 (predicting that the definition of a correctable disability will be a focal point of future litigation).

14. There is already some indication that plaintiffs are invoking the Sutton opinion to argue that the side effects of their corrective measures are independenuly disabling. See. e.g.. Belk v. Southwestern Bell Tel., 194 F.3d 946, 950 (8th Cir. 1999); Marasovich v. Prairie Material Sales, No. 98 C 2070, 1999 U.S. Dist. LEXIS 18682, at *16 (N.D. Ill. Dec. 1. 1999).

15. Clemetson, supra note 8, at 27 (quoting Georgetown law professor Chai Feldblum).

16. The Supreme Court ruled in Bragdon v. Abbont, 524 U.S. 624 (1998), that reproduction is a major life activity under the ADA. Thus, an individual whose drug therapies increase the risk of birth defects might be appropriately considered an individual with a disability for the purposes of an ADA claim, though it would undoubtedly be difficult to demonstrate that the individual was discriminated against on the basis of that disability. 
disabling treatments. The effect of the Sutton opinion would be to target the ADA's protections in a manner that would achieve a proper balance between the statute's protective goals and the Supreme Court's apparent desire to reduce frivolous litigation and to protect the autonomy of employers' decisions regarding the terms and conditions of employment.

The relatively few judicial opinions that have addressed disabling corrections, however, have not applied that concept expansively. The courts seem disinclined to view corrective measures as disabilities, especially when, as is frequently the case, their adverse effects are transient in nature. At least two courts have even indicated a willingness to second-guess employees and their doctors by permitting employers to question the need for and appropriateness of such disabling corrections.

This Note argues that the concept of disabling corrections alluded to in Sutton has the potential to strike an appropriate balance between the ADA's rather explicit goal of encouraging and enabling individuals with disabilities to participate in the workplace and its countervailing goal, captured in the correctable disabilities cases, of shielding employers and courts from burdensome litigation filed by plaintiffs with minor or trivial impairments. This potential will be realized, however, only if the Equal Employment Opportunity Commission (EEOC) and the lower courts make a conscious effort to conceptualize disabling corrections broadly and to give proper deference to the informed judgment of employees who face the unattractive choice between living with existing disabilities and subjecting themselves to potentially disabling corrective measures. Part I introduces the ADA, the correctable disabilities decisions, and the "disabling corrections" language contained therein. Part II analyzes past federal-court opinions addressing disabling corrections and discusses the reasoning behind the apparent disinclination of courts to define such corrective measures as disabilities under the ADA. Part III suggests that the EEOC amend its implementing regulations under Title I of the ADA to facilitate broader applicability of the ADA to individuals who must use disabling corrections to mitigate other impairments. Finally, Part IV discusses the importance of judicial and employer deference to the judgment of employees and their treating physicians in accommodating and protecting the rights of such individuals.

\section{THE ADA AND THE CORRECTABLE DisABILITIES CASES}

\section{A. The History and Goals of the ADA}

The ADA was enacted in 1990 in response to growing public awareness and concern about discrimination against people with disabilities and the effects of such discrimination on the economic and employment 
opportunities available to these individuals. ${ }^{17}$ The Act's statutory precursor was the Rehabilitation Act of 1973, which prohibited "any program or activity receiving Federal financial assistance" from discriminating against an individual "solely by reason of his handicap." 18 The ADA extends this nondiscrimination mandate to private employers (Title I); ${ }^{.9}$ state and local governments (Title II); ${ }^{20}$ and other private entities that provide public accommodations (Title III). ${ }^{21}$ In the employment context, Title I prohibits discrimination "against a qualified individual with a disability because of the disability of such individual in regard to job application procedures, the hiring, advancement, or discharge of employees, employee compensation, job training, and other terms, conditions, and privileges of employment." 22 The discriminatory behaviors prohibited by the Act include "limiting, segregating, or classifying" an individual adversely because of a disability, using criteria or tests that have a discriminatory effect, and failing to provide reasonable accommodations to allow an employee with a disability to participate fully in the workplace..$^{23}$

The ADA is unquestionably a pro-work statute. The plain language of the statute, its legislative history, and the legislative findings included in it all evince a clear intent on the part of Congress to encourage and enable individuals with disabilities to obtain and retain employment. ${ }^{24}$ At the time of the ADA's enactment, numerous studies indicated that the involuntary unemployment rate of individuals with disabilities was appallingly high..$^{25}$ This involuntary unemployment was attributed to rampant workplace discrimination against individuals with disabilities. The congressional committees that considered the ADA in its early stages were influenced not only by the injustice of such prejudice, but also by the economic consequences of employers' discriminatory practices. The House Committee on Education and Labor's favorable report on the Act gave considerable credence to testimony in the hearing record indicating that the exclusion of such individuals from participation in the national economy

17. For an in-depth analysis of the origins of the ADA, see Robert L Burgdorf. Jr.. The Americans with Disabilities Act: Analysis and Implications of a Second-Generation Civil Rights Statute, 26 HARV. C.R.-C.L. L. REV. 413, 415-34 (1991).

18. Rehabilitation Act of 1973, Pub. L. No. 93-112, §504, 87 Stat. 355, 394 (1973). The Rehabilitation Act definition of disability is now the same as the ADA's stalutory definition. See 29 U.S.C. $\$ 794($ a) (1994). The term "disability" is now preferred over the term "handicap." although there is no difference in their legal meaning. See H.R. REP. No. 101-485, pt. 2, at 50-51 (1990), reprinted in 1990 U.S.C.C.A.N. 303, 332-33.

19. See 42 U.S.C. $\S \$ 12111-12117$ (1994).

20. See id. \$§ 12131-12165.

21. See id. \$§ 12181-12189.

22. Id. \$ 12112(a).

23. Id. \$ 12112(b).

24. See, e.g., Mary Crossley, The Disability Kaleidoscope, 74 NOTRE DAME L. REV. 621. 634-35 (1999).

25. See, e.g., Burgdorf, supra note 17, at 420-26 (discussing the results of several studies). 
cost the United States billions of dollars each year. ${ }^{26}$ Such economic losses were attributable both to the cost of providing social support programs and to the loss of productivity, earnings, and income tax payments that resulted from the exclusion of individuals with disabilities from full participation in the economy. The Committee concluded that "to the extent that the changes in practices and attitudes brought about by the implementation of the Act ultimately assist people with disabilities in becoming more productive and independent members of society, both they and our entire society benefit." 27

This dual emphasis on autonomy and economic considerations was incorporated into the statutory findings as well. Congress emphasized that employment opportunities were critical to "the Nation's proper goals regarding individuals with disabilities," including the assurance of "equality of opportunity, full participation, independent living, and economic self-sufficiency." 28 Moreover, Congress felt that improved employment opportunities would serve the important national economic goal of decreasing the "billions of dollars in unnecessary expenses resulting from dependency and non-productivity" of these individuals. ${ }^{29}$ These findings indicate that the ADA was intended to be a pro-work statute and that Title I's provisions were clearly designed to remedy discrimination that might prevent individuals with disabilities from participating in the workplace to the fullest extent possible.

\section{B. The ADA Definition of Disability}

Unlike prior civil rights laws, the ADA and the Rehabilitation Act targeted a group that is neither discrete nor well-defined. These antidiscrimination statutes are unique in that plaintiffs seeking to invoke the laws' protections are not presumptively assumed to be members of the group that the law was designed to protect. Though it was rare for a defendant to challenge a plaintiff's ability to meet the statutory definition of disability in early ADA litigation, there has been a marked increase in the frequency of such challenges in recent years. ${ }^{30}$ Today, one of the most highly contested aspects of the ADA is how the law defines an "individual with a disability."

26. See H.R. REP. No. $101-485$, pt. 2, at 43-47 (1990), reprinted in 1990 U.S.C.C.A.N. 303, $325-29$.

27. Id. at $45-46$, reprinted in 1990 U.S.C.C.A.N. at 327-28.

28. 42 U.S.C. $\S 12101(\mathrm{a})(8)$.

29. Id. $\$ 12101(\mathrm{a})(9)$.

30. See, e.g., Crossley, supra note 24 , at 623 ; Steven S. Locke, The Incredible Shrinking Protected Class: Redefining the Scope of Disability Under the Americans with Disabilities Act, 68 U. COLO. L. REV. 107, 112-13 (1997). 
Using a three-prong test, the ADA defines a disability as
(A) a physical or mental impairment that substantially limits one or more of the major life activities of such individual;
(B) a record of such an impairment; or
(C) being regarded as having such an impairment. ${ }^{3 t}$

Congress delegated the authority to interpret and implement Title I of the

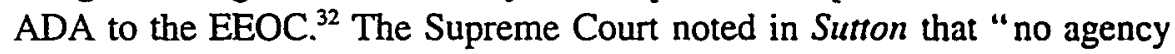
has been delegated the authority to interpret the term "disability," 33 because the definition of the term is contained in a generally applicable provision of the statute. ${ }^{34}$ Nevertheless, the EEOC has promulgated regulations indicating its interpretation of the ADA definition of disability in the context of employment. ${ }^{35}$ These regulations expand on the meaning of each of the necessary components of the statutory definition of disability: (1) the existence of a mental or physical impairment ${ }^{36}$ that (2) substantially limits $^{37}$ (3) a major life activity. ${ }^{38}$ The EEOC interpretive guidance that accompanies these regulations also indicates that a determination of disability is to be made "without regard to mitigating measures such as medicines, or assistive or prosthetic devices." ${ }^{39}$

\section{The Correctable Disabilities Cases}

Prior to the Supreme Court's decisions in the correctable disabilities cases, there was significant disagreement as to whether mitigating measures should be considered when determining whether or not an individual met

\footnotetext{
31. 42 U.S.C. \& $12102(2)$.

32. See id. § $12117($ a).

33. Sutton v. United Air Lines, 119 S. C. 2139, 2145 (1999).

34. See 42 U.S.C. $\S 12102(2)$.

35. See 29 C.F.R. $\$ 1630.2(\mathrm{~g})$ (1998).

36. The regulations define a physical or mental impairment as

[a]ny physiological disorder, or condition, cosmetic disfigurement, or anatomical loss affecting one or more of the following body systems: neurological, musculoskeletal. special sense organs, respiratory (including speech organs) cardiovascular. reproductive, digestive, genito-urinary, hemic and lymphatic, skin and endocrinc or ... [a]ny mental or psychological disorder, such as mental retardation, organic brain syndrome, emotional or mental illness, and specific leaming disabilities.
} Id. $\S 1630.2(\mathrm{~h})(1)-(2)$.

37. The regulations define "substantially limits" to mean "[u]nable to perform a major life activity that the average person in the general population can perform" or to mean "[s]ignificanuly restricted as to the condition, manner or duration under which an individual can perform a particular major life activity as compared to the condition, manner, or duration under which the average person in the general population can perform that same major life activity." Id. $\S 1630.2(j)(1)$.

38. The regulations define a major life activity to mean "functions such as caring for oneself, performing manual tasks, walking, seeing, hearing, speaking, breathing. learning, and working." Id. $\$ 1630.2(\mathrm{~h})(2)(\mathrm{i})$.

39. Id. pt. 1630 app. at 347. 
the ADA's definition of disability. ${ }^{40}$ Eight circuits had adopted the EEOC's position that impairments should be evaluated in their uncorrected or unmitigated state when determining the applicability of the ADA." This position was justified by the agency's view that consideration of impairments in an unmitigated state best upheld the statutory purpose of the ADA. ${ }^{42}$ The EEOC also maintained that disregarding mitigating measures in a determination of disability was "most consonant with the structure of the statute, which generally addresses at a stage later than the threshold determination of disability issues regarding the various adjustments that may be required to enable a disabled person to work." ${ }^{43}$ As the dissent in Sutton pointed out, the legislative history of the Act also strongly favored this interpretation. ${ }^{44}$

Conversely, prior to the correctable disabilities decisions, both the Sixth and Tenth Circuits had taken the position subsequently adopted by the Supreme Court: that an individual's impairment should be evaluated in its corrected or mitigated state for the purposes of the ADA. ${ }^{45}$ These courts based their rejection of the EEOC position largely on their concern that the

40. See, e.g., Timothy Stewart Bland, The Determination of Disability Under the ADA: Should Mitigating Factors Such as Medications Be Considered?, 35 IDAHO L. REv. 265 (1999); Erica Worth Harris, Controlled Impairments Under the Americans with Disabilities Act: A Search for the Meaning of "Disability," 73 WASH. L. REV. 575 (1998); Jonathan Bridges, Note, Mitigating Measures Under the Americans with Disabilities Act: Interpretation and Deference in the Judicial Process, 74 Notre DAME L. REv. 1061 (1999); Elizabeth A. Chang, Note. Who Should Have It Both Ways? The Role of Mitigating Measures in an ADA Analysis, 64 BROOK. L. REV. 1123 (1998); Sheryl Rebecca Kamholz, Note, The Americans with Disabilities Act: Advocating Judicial Deference to the EEOC's Mitigating Measures Guidelines, 8 B.U. PUB. INT. L.J. 99 (1998); Michael J. Puma, Note, Respecting the Plain Language of the ADA: A Textualist Argument Rejecting the EEOC's Analysis of Controlled Disabilities, 67 GEO. WASH. L. REV. 123 (1998); Maureen R. Walsh, Note, What Constitutes a "Disability" Under the Americans with Disabilities Act: Should Courts Consider Mitigating Measures?, 55 WASH. \& LEE L. REV. 917 (1998).

41. See Bartlett v. New York State Bd. of Law Exam'rs, 156 F.3d 321, 329 (2d Cir. 1998); Washington v. HCA Health Servs., 152 F.3d 464, 470-71 (5th Cir. 1998); Baert v. Euclid Beverage, 149 F.3d 626, 629-30 (7th Cir. 1998); Amold v. United Parcel Serv., 136 F.3d 854, 863 (1st Cir. 1998); Matczak v. Frankford Candy \& Chocolate Co., 136 F.3d 933, 937 (3d Cir. 1997); Doane v. City of Omaha, 115 F.3d 624, 627 (8th Cir. 1997); Harris v. H \& W Contracting Co., 102 F.3d 516, 520-21 (11th Cir. 1996); Holihan v. Lucky Stores, 87 F.3d 362, 366 (9th Cir. 1996).

42. See Brief for the United States and the EEOC as Amicus Curiae Supporting Petitioners at 7, Sutton v. United Air Lines, 119 S. Ct. 2139 (1999) (No. 97-1943), available in 1999 WL 95496 [hereinafter EEOC amicus brief].

43. Id. at 8 .

44. See Sutton, 119 S. Ct. at 2154-56 (Stevens, J., dissenting); see also Issac S. Greancy, Note, The Practical Impossibility of Considering the Effect of Mitigating Measures Under the Americans with Disabilities Act of 1990, 26 FORDHAM URB. L.J. 1267, 1272-74 (1999) (noting that Congress did not want the courts to consider mitigating measures).

45. See Sutton v. United Air Lines, 130 F.3d 893, 902 (10th Cir. 1997), aff'd, $119 \mathrm{~S}$. Ct. 2139; Gilday v. Mecosta County, 124 F.3d 760, 767 (6th Cir. 1997). The Fourth Circuit also declined to defer to the EEOC regulations in Runnebaum v. Nationsbank of Maryland, 123 F.3d 156 (4th Cir. 1997), when the court failed to consider whether an HIV-positive individual would have been substantially impaired in a major life activity absent the mitigating effects of his drug therapies. See id. at $183 \mathrm{n} .9$ (Michael, J., dissenting). 
EEOC's guidelines required courts to inquire into the impact of a corrected disability in a hypothetical uncorrected state. ${ }^{46}$ Similarly, while the Fourth Circuit did not explicitly reject the EEOC guidelines prior to Sutton, the court expressed concern that the EEOC position would debase the ADA by demanding that the statutory protections available to those with severe impairments also be made available to those with comparatively minor conditions. ${ }^{47}$

Because the Supreme Court's decisions in the "correctable disabilities cases" rejected the position of the overwhelming majority of circuit courts, these decisions portend a significant change in the population of individuals who are accorded protection under the ADA. Reduced to their most basic holding, Albertsons, Murphy, and Sutton establish that "the determination of whether an individual is disabled should be made with reference to measures that mitigate the individual's impairment." 48 Thus, individuals who can treat or compensate for their impairments and thereby function "normally" do not qualify for the protections of the ADA. Closer examination reveals, however, that these opinions contain important nuances that are not captured in a simple statement of their holdings.

In Sutton - the leading case in this series of decisions-twin sisters with severe myopia applied for employment with United Airlines as commercial airline pilots. Both Karen Sutton and her sister, Kimberly Hinton, had uncorrected vision of 20/200 or worse in both eyes and were rejected because of United's minimum vision standard, which required uncorrected visual acuity of $20 / 100$ or better in each eye. The sisters sued United, claiming that they were rejected because of their disabilities or because United regarded them as having disabilities. In support of their contention that they were individuals with disabilities within the meaning of the ADA, Sutton and Hinton argued that their myopia significantly interfered with their ability to engage in the major life activity of working. They claimed that the court should look at their visual impairments in an uncorrected state, as per the EEOC guidelines. The district court dismissed their suit, stating that, because their vision was fully correctable, Sutton and Hinton had not demonstrated that they were individuals with disabilities or "regarded as" individuals with disabilities within the meaning of the ADA. ${ }^{49}$ The Court of Appeals for the Tenth Circuit affirmed. ${ }^{\text {so }}$

The Supreme Court upheld the Tenth Circuit's ruling. In examining the petitioners' contention that the EEOC guidelines required the Court to

46. See, e.g., Sutton, 130 F.3d at 902.

47. See, e.g., Forrisi v. Bowen, 794 F.2d 931, 934 (4th Cir. 1986).

48. Sutton, $119 \mathrm{~S}$. Ct. at 2143.

49. See Sutton v. United Air Lines, No. 96-S-121, 1996 U.S. Dist. LEXIS 15106, at "18 (D. Colo. Aug. 28, 1996).

50. See Sutton, 130 F.3d at 895 . 
consider their disabilities in an uncorrected state, the Court questioned the EEOC's authority to issue guidelines interpreting the statutory definition of disability, noting that the definition of disability was contained in a portion of the statute that no agency had been specifically authorized to implement. $^{51}$ Though the Court did not ultimately rule on the EEOC's authority to promulgate guidelines or regulations interpreting the statutory definition of disability, it found the requirement that a determination of disability be based on consideration of the individual's impairment in an uncorrected state to be in conflict with the plain meaning of the statute. ${ }^{52}$

The Court provided three justifications for its reading of the statute. Initially, the majority noted that the first prong of the ADA's three-prong definition defines a disability as "a physical or mental impairment that substantially limits one or more of the major life activities" of an individual. ${ }^{53}$ Because the verb "limits" in this phrase appears in the present indicative form, the Court ruled that the ADA requires an individual to be "presently-not potentially or hypothetically - substantially limited" in order to demonstrate a disability under this prong of the definition. ${ }^{54}$ Second, the Court observed that the statutory definition of a disability demands an individualized inquiry into the particular effects of the impairment on the individual's major life activities. The Court suggested that examination of impairments in an uncorrected state would be less conducive to such an individualized inquiry because any determination of the actual practical effect of the impairment would be speculative. ${ }^{55}$ The Court also explained that examination of uncorrected impairments would be inconsistent with the "individualized inquiry requirement," because it would not permit courts and employers to consider appropriately the impact of any negative side effects on the individual's major life activities that might be caused by mitigating measures. ${ }^{56}$ Finally, the Court noted that the statute's findings include a statement that forty-three million individuals in the United States were thought to have one or more physical or mental disabilities. The majority argued that this number would have been much higher had Congress intended to include "correctable disabilities" within the statutory definition of a disability. ${ }^{57}$

In response to the dissent's argument that viewing individuals in their corrected state created an overly exclusive definition of disability, the majority emphasized that many individuals who take measures to mitigate their impairments would still be considered to have disabilities under the

51. See Sutton, 119 S. Ct. at 2145.

52. See id. at 2146.

53. Id. (quoting 42 U.S.C. \$ 12102(2)(A) (1994)).

54. Id.

55. See id. at 2147.

56. See id.

57. See id. at 2147-49. 
majority's conception. They pointed out that individuals with prosthetic limbs, for example, "may be mobile and capable of functioning in society but still be disabled because of a substantial limitation on their ability to walk or run." 58 The majority clarified that "[t]he use or nonuse of a corrective device does not determine whether an individual is disabled; that determination depends on whether the limitations an individual with an impairment actually faces are in fact substantially limiting." 59 Thus, individuals who can correct their disabilities to the point where they can "function in society" or in the workplace may still be considered to have disabilities as long as a major life activity (such as walking, seeing, speaking, or reproduction) is substantially impaired, notwithstanding the correction.

The Court also rejected the plaintiffs' claim that United Air Lines "regarded" them as having disabilities. Relying upon the EEOC regulations, ${ }^{60}$ the Court explained that individuals must prove that they are regarded as ineligible for an entire category of jobs, not just a particular position, in order to demonstrate that they are perceived to be incapable of working. ${ }^{61}$ In explaining this line of reasoning, the Court pointed out the petitioners' failure to make "the obvious argument that they are regarded due to their impairments as substantially limited in the major life activity of seeing," ${ }^{2}$ and hinted that claims based on perceived limitations affecting the ability to work should generally be viewed less favorably than claims based on other major life activities. ${ }^{63}$ The Court determined that Sutton and Hinton had not demonstrated that they were excluded from an entire category of jobs and thus could not have been "regarded as" having a disability that significantly limited their ability to work.

In Sutton's companion cases, Murphy v. United Parcel Service and Albertsons, Inc. v. Kirkingburg, the Supreme Court similarly rejected the $\mathrm{ADA}$ claims of individuals whose corrected impairments did not limit a

58. Id at 2149 .

59. Id.

60. In this section of the opinion, the majority "assum[ed] without deciding" that the EEOC's definitional regulations were reasonable, despite their previous questioning of the authority under which such regulations were promulgated. Id. at 2151 . Presumably, the Court felt that the EEOC's interpretation of the term "substantially limits" was not in conflict with the plain meaning of the statute. This portion of the majority opinion could be read to indicate that. absent a conflict with the plain meaning of the statute, the EEOC's definitional regularions and interpretive guidance are still entitled to judicial deference.

61. See id. at 2151.

62. Id. at 2150 .

63. See id. at 2151 . One commentator has suggested that the judicial disinclination to rule that an impairment substantially limits the major life activity of working has "effectively emasculated ... [this] provision." Locke, supra note 30. at 138. Locke advocates that working should be eliminated as a major life activity and replaced with a task-based assessment of impairment. See id.

64. See Sutton, 119 S. Ct. at 2152. 
major life activity, relying primarily on the language of the Sutton opinion. In Albertsons, the Supreme Court further clarified its reasoning in Sutton by noting that an individualized inquiry under the ADA must take into account not only treatments and corrections (such as medications or devices), but also the individual's ability to compensate for the impairment, including the brain's unconscious mechanisms for coping with the disability. ${ }^{65}$ Though the plaintiff had a visual impairment that left him with effectively monocular vision, his brain had developed unconscious mechanisms to compensate for his problems with depth perception and peripheral vision. The Court ruled that his visual problems did not necessarily substantially impair a major life activity and that the Ninth Circuit had not given adequate consideration to these mitigating measures. ${ }^{66}$

\section{Sutton's Disabling Corrections Corollary}

In both Sutton and Albertsons, the majority pointedly emphasized that the determination of whether or not a person qualified as an "individual with a disability" under the ADA is a highly individualized inquiry that should be based not on categorical determinations but instead on an investigation into the unique challenges faced by that individual ${ }^{67}$ The Court also emphasized its view that deference to the EEOC's mitigatingmeasures guidelines would have required "courts and employers to speculate about a person's condition and would, in many cases, force them to make a disability determination based on general information about how an uncorrected impairment usually affects individuals, rather than on the individual's actual condition." 68 Such a speculative inquiry into an individual's potential impairment in an uncorrected state would have led "to the anomalous result that in determining whether an individual is disabled, courts and employers could not consider any negative side effects suffered by an individual resulting from the use of mitigating measures, even when those side effects are very severe." ${ }^{69}$ The Court cited three examples of such potentially disabling corrections: antipsychotic drugs, which "can cause... neuroleptic malignant syndrome and painful seizures"; drugs used to treat Parkinson's disease, which "can cause liver

65. See Albertsons, Inc. v. Kirkingburg, 119 S. Ct. 2162, $2168-69$ (1999).

66. See id.

67. See id. at $2169 ;$ Sutton, 119 S. Ct. at 2147.

68. Sutton, 119 S. Ct. at 2147.

69. Id. (emphasis added). The dissent questioned the majority's conclusion that examination of disabilities in their unmitigated state would prevent consideration of the effects of disabling corrections, arguing that in the rare instance in which an individual suffered disabling side effects in treating an underlying condition that was not, in and of itself, disabling, "it might fairly be said that ... side effects are symptomatic of a disability because side effects and a physical impairment may flow from the same underlying condition." Id. at 2159 n.5 (Stevens, J., dissenting). 
damage"; and anti-epileptic drugs, which can cause "serious negative side effects." 70

With this discussion of the importance of including disabling corrections in a determination of disability, the Court created an important corollary to the "rule" that individuals who can utilize corrective measures to mitigate the effects of their original impairments are not generally entitled to the ADA's protections. ${ }^{71}$ Lower courts should interpret this corollary generously in order to harmonize the implicit litigation-limiting goal of the correctable disabilities cases with the ADA's broader goal of empowering individuals with disabilities.

Many initial interpretations of the correctable disabilities decisions have applauded the Court for making a "common sense decision" that will ensure that the courts are no longer "flooded" with workplace discrimination claims based on minor or insignificant impairments. "While there may be reason to question the empirical basis for this fear, ${ }^{73}$ even assuming that the definition of "disability" espoused by the EEOC and a majority of the courts of appeals did result in a flood of specious litigation, any narrowing of the ADA's protected class in response to this extrastatutory concern should be carefully tailored to eliminate only those plaintiffs who are manifestly beyond the class of citizens with disabilities that Congress meant to protect. The disabling corrections corollary limits the narrowing effect of the correctable disabilities decisions to exclude only those individuals who can correct their impairments without significant adverse side effects. By targeting the impact of the correctable disabilities decisions in this manner, the disabling corrections corollary helps to ensure that the Sutton decision will clarify, not destroy, the protections of the ADA. This beneficial outcome will be realized only if lower courts vigilantly maintain the breadth of the disabling corrections corollary and thus ensure that meritorious claims are not improperly rejected at the summary judgment stage. ${ }^{74}$

70. Id. at 2147 (citations omitred).

71. This "rule" may seem a somewhat oversimplified encapsulation of the holding in the correctable disabilities cases. Lower courts have nonetheless adopted this interpretation of the Supreme Court's recent decisions. See, e.g., Baker v. Chicago Park Dist.. No. 98 C 4613, 1999 U.S. Dist. LEXIS 11225, at *8 n.2 (N.D. Ill. July 15, 1999) (noting that "the Supreme Court has restricted the definition of a disability to conditions that are not medically correctsble").

72. See, e.g., Disability Distinctions, St. PETERSBURG TIMES, Junc 26. 1999. at 18A: Jobs Laws, FIN. TIMES (London), June 25, 1999, at 13 (arguing that federal judges are "overwhelmed" with employment cases and that "the ruling may safeguard the Act ... already famous for the frivolity of cases brought under it").

73. See, e.g., Ruth Colker, The Americans with Disabilities Act: A Windfall for Defendants, 34 HARV. C.R.-C.L. L. REV. 99, 106 (1999); Paul Steven Miller, The Americans with Disabilities Act in Texas: The EEOC's Continuing Efforts in Enforcement, 34 Hous. L. REv. 777, 790 (1997).

74. There is already a strong indication that lower courts are interpreting the correctable disabilities decisions in a manner that severely limits the applicability of the ADA to those who utilize corrective measures. While many courts interpreting Sutton have rejected the ADA claims 
Moreover, a generous interpretation of the disabling corrections corollary would serve the larger goals of the ADA. As noted above, both the legislative history of the ADA and the language of the statute itself indicate that the Act was intended to encourage and enable individuals with disabilities to work and participate in the economy whenever possible. Enabling increased participation in the national economy by individuals with disabilities protects the rights of these individuals and serves national economic interests as well. Ensuring that individuals who attempt to correct their disabilities are protected from discrimination in the workplace if these corrections are themselves disabling will encourage such individuals to take aggressive steps to mitigate their impairments and thereby enhance their ability to remain self-sufficient participants in the economy.

\section{LOWER-COURT RECEPTIVENESS TO DISABLING CORRECTIONS PRIOR TO SUTTON}

The concept of a disabling correction did not appear for the first time in Sutton. Some federal courts had already (implicitly or explicitly) acknowledged that the side effects of corrective measures can constitute a disability for the purposes of the ADA prior to the Supreme Court's correctable disabilities decisions. ${ }^{75}$ Sutton's explicit statement that those with disabling corrections are still eligible for the ADA's protections will undoubtedly increase the frequency with which plaintiffs argue that they are appropriately considered individuals with disabilities due to a disabling

of individuals who sought to be evaluated in an uncorrected state, see, e.g., Haiman v. Village of Fox Lake, 55 F. Supp. 2d 886 (N.D. IIl. 1999), a few post-Sutton courts also have rejected the ADA claims of individuals whose corrective measures were malfunctioning at the time of termination, see, e.g., Todd v. Academy Corp., 57 F. Supp. 2 d 448 (S.D. Tex. 1999), whosc corrective measures were not prescribed until after the time of termination, see., e.g., Taylor $v$. Blue Cross \& Blue Shield, Inc., 55 F. Supp. 2d 604 (N.D. Tex. 1999), or whose corrective measures were unable to correct completely the effects of the underlying condition, see, e.g.. Rutlin v. Prime Succession, Inc., No. 98-CV117, 1999 U.S. Dist. LEXIS 8754 (W.D. Mich. Junc 9, 1999). (Though the Rutlin decision was handed down prior to Sutton, applicable precedent in the Sixth Circuit at the time instructed trial courts to consider the effects of mitigating measures.) But see Belk v. Southwestern Bell Tel., 194 F.3d 946, 950 (8th Cir. 1999) (determining that the plaintiff was appropriately considered an individual with a disability due to the side effects of his corrective leg braces); Marasovich v. Prairie Material Sales, No. 98 C 2070, 1999 U.S. Dist. LEXIS 18682, at *16 (N.D. Ill. Dec. 1, 1999) (determining that there was a genuine issue of material fact as to whether the side effects of the plaintiff's medications substantially limited his ability to work).

75. See, e.g., Gilday v. Mecosta County, 124 F.3d 760, 766 (6th Cir. 1997) (Kennedy. J.. concurring in part and dissenting in part); Gordon v. E.L. Hamm \& Assocs., 100 F.3d 907 (11th Cir. 1996); Berk v. Bates Adver. USA, 25 F. Supp. 2d 265 (S.D.N.Y. 1998); Hodgens v. General Dynamics Corp., 963 F. Supp. 102 (D.R.I. 1997). But cf. Lester v. Trans World Airlines, No. 95C2349, 1997 U.S. Dist. LEXIS 10857 (N.D. Ill. July 23, 1997) (declining to consider whether side effects should be part of the determination of disability). 
correction. ${ }^{76}$ This shift in focus by plaintiffs is likely to stimulate innovative responses by employers aimed at narrowing the "disabling corrections corollary" to the correctable disabilities rule. Future courts will grapple with difficult questions in attempting to evaluate these claims: How severe must a side effect be before it should be considered disabling? Should severe but temporary side effects be considered disabilities for the purposes of the ADA? May an employer second-guess an employee's choice by refusing to accommodate corrections that the employer deems to be unnecessary or inappropriate? Can an employer legitimately fire someone who refuses to utilize a disabling correction to mitigate an impairment?

Unfortunately, very few precedents exist to indicate how courts will answer these questions in the future, since the law in eight circuits prior to Sutton required courts to consider an impairment in its unmitigated or uncorrected state. ${ }^{7}$ Under this regime, courts evaluated whether the underlying impairment was itself a disability; there was no need to consider the potentially disabling effects of treatments. ${ }^{78}$ The few relevant precedents contain hints of a past judicial reluctance to accept corrective measures as disabilities, and a corresponding tendency to create a de facto higher standard of proof for establishing a disability when the impairment stems from a corrective measure. These cases also indicate a judicial receptivity to employer arguments that employees who elect to undergo "unnecessary" or "inappropriate" corrections, however disabling, are not entitled to the ADA's protections. Judicial tolerance of such arguments is improper. Acceptance of the former argument runs counter to the ADA's pro-work policy, while acceptance of the latter has the potential both to impinge unduly upon the autonomy of individuals with disabilities and to burden the courts with complex but only marginally relevant factual disputes.

76. See, e.g., Todd, 57 F. Supp. $2 d$ at 454 (involving a plaintiff who, after the Sutron decision, argued that the side effects of his epilepsy medication were disabling).

77. See supra note 41 and accompanying text.

78. For example, in Wright v. Ciry of Tampa, 998 F. Supp. 1398 (M.D. Fla. 1998), a district court in Florida considered whether an individual with thrombocythemia (a blood disorder that can cause weakness, dizziness, hemornaging, and increased risk of stroke, heart altack, or embolism if left untreated) was an individual with a disability within the meaning of the ADA. Though the blood condition was treated with medication, the plaintiff alleged that the medication used to treat the condition resulted in chronic headaches and fatiguc. See id. at 1399. In ruling on the defendant's motion for summary judgment, the cour considered the impact of the thrombocythemia in its uncorrected state and thus found that the plaintiff had presented a genuine issue of material fact as to whether she met the ADA definition of an "individual with a disability" due to her blood disorder. See id. at 1402. The cour never discussed whether the side effects of the medicine could have been considered a disabling condition. 


\section{A. The Severity of the Side Effect}

Those courts that have examined the applicability of the ADA to individuals with potentially disabling corrections have determined (quite logically) that any disabling correction must meet the same statutory definition of a disability as an uncorrected impairment. ${ }^{79}$ Most importantly, the side effects of the corrective measure must substantially limit the individual's ability to engage in a major life activity. Courts in post-Sutton litigation over disabling corrections will no doubt demand that employees demonstrate that the effects of their corrective measures clearly constitute a disability before ordering employers to take steps to accommodate such employees.

Many of these pre-Sutton courts have been reluctant to conclude that a corrective measure can substantially limit a major life activity. For example, both the Fifth and Eleventh Circuits have recently held that individuals who were undergoing treatments for cancer were not substantially impaired in their ability to work by the side effects of these treatments. In Ellison v. Software Spectrum ${ }^{80}$ the plaintiff alleged that her position was eliminated because of the lower performance evaluation that she received while she was working a modified schedule to accommodate her cancer treatments. The Fifth Circuit rejected the plaintiff's attempt to invoke the protections of the ADA, despite the fact that her radiation treatments caused "nausea, fatigue, swelling, inflammation, and pain" to such an extent that she "constantly felt sick and fatigued." ${ }^{81}$ Because the plaintiff admitted that she could perform the essential functions of her job even while experiencing these side effects, the court ruled that she was not substantially impaired in her ability to work, and thus was not an individual with a disability within the meaning of the ADA..$^{82}$ Similarly, in Gordon $v$. E.L. Hamm \& Associates, ${ }^{83}$ the plaintiff alleged that the terms and conditions of his employment (including his task assignments and his access to a company car) changed during the time period that he was working a modified schedule to accommodate his cancer treatments. The Eleventh Circuit rejected his ADA claim, ruling that the weakness, nausea, dizziness, swelling, numbness, loss of body hair, and vomiting that the plaintiff experienced as a result of chemotherapy treatments were not

79. See, e.g., Gordon, 100 F.3d at 911-12; Hodgens, 963 F. Supp. at 108 (using the ADA definition of a disability to evaluate the disabling impact of side effects).

80. 85 F.3d 187 (5th Cir. 1996).

81. Id. at 191 .

82. See id. at 193.

83. 100 F.3d 907. 
disabling because his doctor found him to be tolerating his treatments "fairly well" and accordingly certified him as capable of working."

Courts have also invoked the EEOC regulations to justify findings that corrective measures were not disabilities. ${ }^{85}$ For example, in Foreman $v$. Babcock \& Wilcox $\mathrm{Co}^{8}{ }^{86}$ the Fifth Circuit ruled that a man who used a pacemaker to correct a heart condition was not substantially impaired in his ability to work. After the installation of his pacemaker, the plaintiff was unable to perform the tasks required for his previous position because these tasks required him to work in close proximity to equipment that might cause electromagnetic interference with his pacemaker. Nevertheless, the court held that the restrictions on his activities that the device demanded did not limit his ability to perform an entire class of jobs as required by the EEOC regulations. ${ }^{87}$

Ellison and Gordon may well have been correctly decided, given that the plaintiff (in one case) and the plaintiff's doctor (in the other) admitted that the side effects of the chemotherapy did not prevent the plaintiffs from engaging in the major life activity of "work." After Sutton, however, the judicial tendency to limit the definition of "disability" to especially severe side effects of medical treatments is no longer justified. Judicial insistence on proof of especially severe side effects has a vast potential to shrink the disabling conditions corollary to the correctable disabilities rule in derogation of both the ADA and the Sutton dicta.

\section{B. The Duration of the Impairment}

The EEOC's regulations directing courts to consider the duration of an individual's impairment in determining whether that impairment is "substantially limiting" may prove particularly problematic for claims based on disabling corrections. Employers faced with such claims will likely argue that they do not have a duty to accommodate any transient limitations on major life activities that stem from corrective treatments or devices.

The EEOC has set forth three factors that should be considered in determining what constitutes a substantial limitation of a major life activity:

84. Id. at 912. District courts have similarly found that the side effects of chemotherapy were not a disabling treatment. See, e.g., Schwertfager v. City of Boynton Beach. 42 F. Supp. $2 d 1347$ (S.D. Fla. 1999); Madjlessi v. Macy's West, 993 F. Supp. 736 (N.D. Cal. 1997).

85. Some courts, however, were disinclined to accord deference to EEOC regulations even prior to Sutton. See, e.g., Colker, supra note 73, at 102, 133-37: Locke, supra note 30. at 109.

86. 117 F.3d 800 (5th Cir. 1997).

87. See id. at 806. The EEOC regulations under Title I of the ADA state that in order to be considered substantially impaired in the major life activity of "working" an individual must be unable to perform an entire class of jobs, not just a particular position. See 29 C.F.R. $\$ 1630.2(j)$ (1998). 
(1) "[t]he nature and the severity of the impairment"; (2) "the duration ... of the impairment"; and (3) the "long-term impact" of the impairment. ${ }^{88}$ The EEOC's technical assistance manual for the ADA further states that temporary, non-chronic impairments that do not last for a long time and have little or no long-term impact usually are not disabilities. ${ }^{89}$ Some courts have interpreted this language to limit the classification of side effects as disabilities under the ADA, especially when those side effects may not be permanent (such as with a therapy of limited duration) or may lessen or stabilize with time (as is the case with many types of side effects). For example, in Wheelock $v$. Philip Morris, ${ }^{90}$ a federal district court in Louisiana found that an individual who experienced drowsiness caused by the drug Klonopin could not appropriately be termed an individual with a disability. Because the plaintiff had discontinued use of the drug at the time of trial and the drowsiness had only been a problem during the time period while the plaintiff was taking the drug, the court determined that the impairment lacked the duration and long-term impact required for classification as a disability. ${ }^{11}$ Moreover, the court in Wheelock went on to state that though the plaintiff had not complained of side effects resulting from the drug (Serzone) that he was taking at the time of trial, any such side effects would also be temporary, given that the underlying condition that these drugs were being used to treat (anger and depression) was, in the court's view, a transitory condition for the plaintiff. ${ }^{92}$ Similarly, in Taylor $v$. Dover Elevator Systems, ${ }^{93}$ a federal district court in Mississippi determined that the emotional impairments that the plaintiff might have suffered as a side effect of the epilepsy drug Felbatol did not constitute a disability within the meaning of the ADA. Because the plaintiff admitted that the emotional impairments induced by the drug had affected him "on a very temporary basis" without any long-term disabling effect, the court ruled that, as per the EEOC regulations, the temporary side effects of the drugs did not substantially limit the plaintiff's ability to engage in any major life activity. ${ }^{94}$

The "duration" requirement has also prevented cancer patients from successfully bringing ADA claims against their employers based on the impairments resulting from cancer treatments. For example, in

88. 29 C.F.R. $\S 1630.2(j)(2)$.

89. See U.S. EQUAL EMPLOYMENT OPPORTUNITY COMM'N, A TEChNICAL ASSISTANCE MANUAL ON THE EMPLOYMENT PROVISIONS (TITLE I) OF THE AMERICANS WITH DisabILITIES ACT § 2.2(a)(iii) (1992).

90. Civ. A. No. 95-0999, 1997 U.S. Dist. LEXIS 1292 (E.D. La. Feb. 5, 1997).

91. See id. at *19.

92. See id. at $* 20$.

93. 917 F. Supp. 455 (N.D. Miss. 1996).

94. Id. at $460-61$. 
Schwertfager v. City of Boynton Beach, ${ }^{95}$ the plaintiff took a leave of absence from work to have reconstructive surgery performed after a mastectomy. After the surgery, the plaintiff experienced significant discomfort and was unable to change her bandages without daily trips to the hospital for assistance. ${ }^{96}$ According to the plaintiff, the effects of the surgery also impaired her ability to care for, dress, and cook for herself." During the period immediately following her surgery, her work performance suffered and she was offered a demotion by her employer. She refused the offer and filed suit. ${ }^{98}$ The court granted summary judgment to the defendant, ruling that Schwertfager was not properly classified as an individual with a disability because she did not claim to suffer any physical limitations beyond the five-month period immediately following her reconstructive surgery. ${ }^{99}$

Interpreting the EEOC regulations to prohibit the classification of any nonpermanent side effect of a corrective measure as a disability severely limits the scope of the disabling corrections corollary to the correctable disabilities rule. Many individuals who can mitigate otherwise permanently disabling conditions with medications or other corrective measures endure periods of adjustment while introducing new treatments or altering existing treatment regimens. The side effects of drug treatments and other therapies are frequently of uncertain duration. ${ }^{100}$ Many of these effects decrease with time as an individual's body adjusts or as an individual's physician adjusts the dosage of the medication to minimize side effects and drug interactions. ${ }^{101}$ In addition, it often takes significant time to find the correct combination of medicines to treat an individual's condition most effectively. ${ }^{102}$ Individuals who are willing to tolerate severe side effects and lengthy (though not necessarily permanent) periods of adjustment to new therapies in order to treat an underlying condition that might otherwise prevent them from participating in the workplace should not be discouraged from such participation by the threat of discrimination. Such an outcome is inconsistent with both the pro-mitigation and pro-work policy goals of the

95. 42 F. Supp. 2d 1347 (S.D. Fla. 1999).

96. See id. at 1352.

97. See id. at 1359.

98. See id. at 1352.

99. See id. at 1360.

100. See, e.g., MERCK MANUAL OF MEDICAL INFormation 42 (Robert Berkow et al. eds., 1997) (explaining that adverse drug reactions are common and vary in both duration and severity).

101. See, e.g., The Epilepsy Foundation. Medicines for Epilepsy: Side Effects (visited Sept. 12, 1999) <http://www.efa.org/education/meds/other.html> (explaining that individuals with epilepsy experience side effects of anti-seizure medicines more frequently with initial use of a drug or with major dosage changes).

102. See, e.g., The Epilepsy Foundation, Medicines for Epilepsy: The Righs Medicine (visited Sept. 12, 1999) <http://www.efa.org/education/meds/righthtml> (explaining that each person experiences individualized reactions to drug treatments and that finding an appropriate combination of medicines and dosages can be a lengthy process). 
ADA. Moreover, keeping such individuals out of the courtroom does not address the Supreme Court's concern, expressed in the correctable disabilities cases, for limiting specious ADA claims by individuals with easily corrected impairments.

It is important to note that the "duration" and "long-term impact" requirements for establishing a disability are grounded only in the EEOC's regulations and have no foundation in the statutory language or the legislative history of the Act. ${ }^{103}$ The other federal agencies authorized to interpret the ADA (including the Department of Justice and the Department of Transportation) have strongly rejected the exclusion of temporary impairments from the ADA's protections. ${ }^{104}$ In addition, there is no consensus among federal courts as to the appropriateness of classifying a temporary condition as a disability. ${ }^{105}$ Indeed, as one of the drafters of the ADA has opined,

[N]one of the EEOC's gloss on temporary impairments has any basis in regulations issued under the Rehabilitation Act, nor in the legislative history of the ADA .... Nowhere does the legislative history suggest that an otherwise substantially limiting condition should not be considered so because it does not last long enough. ${ }^{106}$

This commentator has also suggested that the EEOC's view that "a condition may not qualify as a disability because it is only temporary or of insufficient duration can be traced to court decisions that have weaknesses and deficiencies limiting their value as convincing legal precedent." 107 The EEOC itself has frequently made "ameliorative comments and concessions" regarding its position to exclude short-term impairments from the definition of disability. ${ }^{108}$ Thus, while the EEOC's regulations interpreting Title I of the ADA are generally entitled to great deference, ${ }^{109}$ greater scrutiny may be appropriate when reviewing the agency's position on short-term impairments.

Moreover, there is some indication in the Sutton opinion itself that the disabling corrections corollary should be read in a manner that does not necessarily exclude corrections whose disabling effects are not permanent. In the majority opinion, Justice O'Connor cites three examples

103. See Robert L. Burgdorf, Jr., "Substantially Limited" Protection from Disability Discrimination: The Special Treatment Model and Misconstructions of the Definition of Disability, 42 VILL. L. REV. 409, 475-76 (1997).

104. See id. at 480.

105. See, e.g., Adams v. Citizens Advice Bureau, 187 F.3d 315, 317 (2d Cir. 1999).

106. Burgdorf, supra note 103, at 479.

107. Id. at 469.

108. Id. at 482. See also id. at 479-81.

109. See, e.g., Heyman v. Queens Village Comm. for Mental Health, 198 F.3d 68, 72 ( $2 \mathrm{~d}$ Cir. 1999). 
of potentially disabling corrective measures: antipsychotic drugs, drug treatments used for Parkinson's disease, and anti-epileptic drugs. Studies of some of the most frequently utilized examples of each of these types of drugs, however, reveal that many of the most severe side effects decline with time or as medication levels are adjusted and drug interactions are minimized. ${ }^{110}$ For example, Loxitane is an antipsychotic whose side effects frequently include neuromuscular reactions such as tremors, rigidity, excessive salivation, and akathisia (motor restlessness) and other Parkinsonian symptoms. ${ }^{111}$ These effects most frequently occur during the initial days of treatment and can generally be controlled in the long term with a gradual reduction in the initial dosage of Loxitane or administration of anti-Parkinsonian drugs. ${ }^{112}$ Thus, though these side effects are of limited duration and likely have no significant long-term impact, there is some indication that the majority in Sutton felt that such effects should be considered in determining whether an individual undergoing such a mental health treatment was entitled to the protections of the ADA.

\section{Employers' Attempts To Second-Guess Medical Decisions}

In addition to demanding strict adherence to both the statutory and regulatory requirements defining "individual with a disability," courts seem inclined (in certain circumstances) to permit employers to question the appropriateness of employees' treatment decisions when these decisions involve a disabling correction. These courts, however, have heretofore appeared unconcerned with the potentially dangerous implications of this judicial tendency. If employers are permitted to challenge the appropriateness of an employee's decision to utilize a disabling correction, then employees will be forced to seek approval from their employers before making important medical decisions. Ultimately, such employees may be forced to allow their employers to dictate the outcome of treatment decisions.

110. Most antipsychotic drugs, including Levora. Navane, or Clorazil, have severe side effects that can impair both mental and physical abilities and potentially cause serious health risks. However, some of the most severe side effects can diminish or disappear after the initial stages of treatment. See PHYSICLANS' DESK REFERENCE 2004-08, 2396-98, 3220-25 (53d cd. 1999). AntiParkinsonian drugs such as Artane, Tasmar, and Requip have side effects ranging from moderate to severe, many of which become less pronounced with continued use, reduction in dosage, or minimization of drug interactions. See id. at 1515-16, 2709-13, 3087-92. Similarly, anti-epileptic drugs such as Mysoline, Klonopin, and Felbatol also have moderate-to-severe side effects that can diminish with time. See id. at 614, 2688-90, 3195-99.

111. See id. at 3224-25.

112. See id. 


\section{The Implicit "Necessary and Appropriate" Requirement}

A number of pre-Sutton cases indicate a desire by employers to secondguess employees' treatment decisions when the side effects of those treatments lead plaintiffs to invoke the protections of the ADA. One preSutton case indicates a willingness to allow employers to substitute their judgments for those of plaintiffs when plaintiffs choose medical procedures to treat conditions that do not rise to the level of disabilities under the ADA. In Christian v. St. Anthony Medical Center, ${ }^{113}$ the plaintiff had an excessive amount of cholesterol in her blood, a condition known as hypercholesterolemia. Though the condition was not itself disabling, the plaintiff alleged that she was fired because "the defendant anticipated that she would undergo a disabling treatment-namely pheresis (or aphereisis), in which the blood is drained from the patient's body, cleansed of its cholesterol, and put back into the patient." 114 Such treatments would have continued throughout the plaintiff's life and would have required the plaintiff to miss a day or two of work each month. The Seventh Circuit readily agreed that a disabling treatment could be considered a disability under the ADA, even if the underlying condition being addressed did not meet the criteria for a disability. ${ }^{115}$ Moreover, the court agreed that if Christian was fired because her employer anticipated that she would have to take time off work to engage in such a disabling treatment, that would also constitute a prima facie case under the ADA. ${ }^{116}$ However, the court raised a caveat that a disabling treatment could "trigger a duty of accommodation" only if it was "truly necessary, and not merely an attractive option." 17 The court suggested that because Christian's doctor was currently prescribing a regimen of drugs and exercise to treat her condition, the pheresis was merely "optional," not a required treatment that would invoke the ADA's protections. This discussion was dictum, however, as the judgment for the defendant ultimately rested upon the court's conclusion that the plaintiff's dismissal was not related in any way to her condition. ${ }^{118}$

At least one federal district court has also addressed, albeit in a somewhat oblique fashion, an employer's contention that a disabling correction must be "necessary" or "appropriate." In Berk v. Bates Advertising USA, ${ }^{119}$ plaintiff Claudia Berk was undergoing treatment for breast cancer. At the time of her diagnosis, she had been informed that "her particular type of breast cancer would put her life at risk if she became

113. 117 F.3d 1051 (7th Cir. 1997).

114. Id. at 1052 .

115. See id.

116. See id.

117. Id.

118. Id. at 1052-53.

119. 25 F. Supp. 2d 265 (S.D.N.Y. 1998). 
pregnant; and that a hysterectomy (surgical removal of the uterus) and bilateral oophorectomy (surgical removal of both ovaries) were advisable precautions against a spread or recurrence of cancer." "220 The plaintiff "reluctantly acted" upon this advice shortly after her employment with Bates was terminated. ${ }^{121}$ A New York district court concluded that

during the period between Berk's return to work at Bates after her cancer surgery and Bates' subsequent termination of her employment, Berk suffered from a physical impairment (cancer and its accompanying possibility of recurrence) which substantially limited the major life activity of reproduction in two ways: the cancer made pregnancy unduly risky for Berk; and the cancer also rendered advisable operations which would destroy any chance of reproduction. ${ }^{122}$

Summary judgment for the defendant was denied because the plaintiff was appropriately classified as an individual with a disability within the meaning of the ADA.

Since the Supreme Court had only recently clarified that reproduction should be considered a major life activity under the $A D A,{ }^{123}$ however, the defendant asked the court to allow it to obtain and to present medical evidence challenging the soundness of the medical advice that Berk had received from her treating physician. ${ }^{124}$ The court declined the request, finding that additional medical testimony would be irrelevant because a medical text relied upon by the defendant stated that delaying or avoiding pregnancy after breast cancer was medically appropriate. ${ }^{125}$

Both of these opinions allow for the possibility that an employer might be able to second-guess an employee's treatment decisions under certain circumstances. Though the Seventh Circuit's holding in Christian did not directly address the disabling corrections question, the tone of the terse opinion suggests that the court would have been sympathetic to an employer's refusal to accommodate a disabling correction if the employer had demonstrated that the treatment was somehow "unnecessary" or "inappropriate." The Berk court did directly address a disabling correction to an ADA disability, and it was not especially sympathetic to the employer's attempt to second-guess the employee's treating physician. The court, however, was strongly influenced by its finding that there was "consensus" in the medical community that the plaintiff's elected treatment

120. Id. at 268 .

121. Id.

122. Id. at 268-69.

123. See Bragdon v. Abbott, 524 U.S. 624, 638-39 (1998).

124. See Berk, 25 F. Supp. $2 d$ at 269.

125. See id. at 269-70. 
was medically appropriate. Had the treatment been experimental or not widely accepted in the medical community, it is unclear whether the court would have permitted the defendant to second-guess the plaintiff's choice.

\section{Employer Pre-Approval of Treatment Decisions}

Judicial willingness to allow employers to second-guess employee treatment decisions may ultimately permit employers to impose their own views about medically appropriate treatments upon the personal medical decisions of any employee with a disability. If courts freely permit afterthe-fact employer challenges to an employee's choices concerning disability-limiting corrections, a cautious employee will likely feel obliged to consult with his or her employer prior to undergoing corrective surgeries or other potentially disabling therapies. Such consultations would be needed not only to inform the employer of the chosen treatment, but also to inquire into the employer's perceptions concerning the medical necessity or appropriateness of the treatment and the employer's willingness to accommodate any potential side effects. In effect, employees may feel compelled to seek pre-approval from their employers before attempting to correct a health problem. The employer would thus become a third participant, along with the employee and his or her physician, in the process of deciding the appropriate course of treatment for the employee's underlying condition. In this situation, the employer could potentially dictate the employee's course of medical treatment, under pain of termination.

The pre-Sutton district-court opinion in Pangalos v. Prudential Insurance $\mathrm{Co}^{126}$ demonstrates that this concern is by no means hypothetical. In that case, the plaintiff was diagnosed with ulcerative colitis, a condition that caused him to suffer from uncontrollable diarrhea, bloody stools, and painful hemorrhoids. The only permanent "cure" for his condition was to undergo a colostomy-the surgical creation of an opening between the colon and the abdominal wall that allows for fecal elimination. This treatment can itself be considered disabling. ${ }^{127}$ The plaintiff, a traveling salesman, elected not to undergo this "drastic alternative" to treat

126. No. 96-0167, 1996 U.S. Dist. LEXIS 15749 (E.D. Pa. Oct. 15, 1996).

127. The side effects of this procedure can include (but are not limited to) swelling and soreness for a period of four to six weeks or more; frequently recurring skin infection, crosion, and ulceration; permanently increased incidence of drug absorption problems; and temporary or long-lasting depression. Moreover, all patients who undergo this surgery must use a rather complicated procedure to evacuate stool (once or twice daily) and many must irrigate the colostomy for bowel control on a daily basis. See, e.g., ADULT NURSING IN HOSPITAL AND COMMUNITY SETTINGS 1419-27 (Lenette Owens Burrell ed., 1992); FundAMENTALS OF: NURSING: THE ART AND SCIENCE OF NURSING CARE 930-32 (Carol Taylor et al. eds., 2d ed. 1993); JUNE M. THOMPSON ET AL., MOSBY'S CLINICAL NURSING 785-89 (4th ed. 1997). 
his condition, ${ }^{128}$ and instead elected the less intrusive, but less effective, "treatment" of paying careful attention to his diet and cleaning up accidents resulting from lack of ready access to toilet facilities. The plaintiff requested that his employer provide him with a van or similar vehicle equipped with a portable bathroom (that would have, in the plaintiff's view, enabled him to perform his job) or reassign him to a job that did not involve travel. As the plaintiff admitted that the cost of the vehicle would have been exceedingly high $(\$ 40,000$ to $\$ 100,000)$, he indicated a preference for reassignment. Though the defendant suggested a number of alternative accommodations, the parties were unable to find a mutually agreeable accommodation prior to litigation. ${ }^{129}$

The Pennsylvania district court initially questioned whether the plaintiff could qualify as an individual with a disability, given that he had rejected a surgical correction for his condition. ${ }^{130}$ Though the court later recognized that only the plaintiff would be entitled to make a decision as to the reasonableness of rejecting the treatment, ${ }^{131}$ the cour came to the conclusion that the plaintiff was mistaken in believing that a vehicle equipped with a bathroom facility would have permitted him to perform effectively the requirements of his current position. ${ }^{132}$ The court held that "[e]ither the plaintiff is not disabled, because the disabling condition... could readily be remedied surgically, or plaintiff is not qualified to perform the essential duties of his position with the defendant." ${ }^{133}$ The Panaglos decision can thus be read to support the conclusion that an employer, consistently with the ADA, may refuse to agree to an expensive accommodation for an employee if that employee can correct his or her condition with a technology or procedure that would be less expensive for the employer to accommodate (regardless of the disabling effects of that treatment on the employee). If this is true, then the employer, without fear of liability under the $\mathrm{ADA}$, may force an employee with a disability to choose between a highly intrusive or even disabling medical procedure and his or her job.

Other instances where employers have attempted to dictate medical therapies abound. Dismissals for failure to undergo "adequate" alcohol abuse therapy, for instance, are exceedingly common. ${ }^{134}$ Even outside the

128. Pangalos, 1996 U.S. Dist. LEXIS 15749, at *3.

129. See id. at *5.

130. See id. at *6.

131. See id. at $* 7$.

132. See id. at *8.

133. Id. Surprisingly, the cour did not inquire into any possible disabling effects of the colostomy. The court further concluded that either there was no feasible accommodation for the plaintiff if he continued to refuse to have a colostomy or that the accommodations offered by the defendant were as a matter of law reasonable. See id.

134. See, e.g., Tim Edwards, Constitutional Limits on an Employer's Right To Dictate the Terms of an Addict's Recovery Under the ADA: Some Sobering Concerns. 44 WAYNE L. REV. 
perhaps distinguishable context of substance-abuse treatments, ${ }^{135}$ employers seem quite willing to dictate or otherwise to manage employee treatment decisions. ${ }^{136}$ Most lower courts have thus far been unreceptive to such attempts. As future plaintiffs increasingly focus judicial attention on disabling corrections, this commendable skepticism should continue to characterize judicial reaction to such claims.

\section{The Dangers of Second-Guessing}

The prospect that employer (or judicial) preferences will play a significant role in private health care decisionmaking is unsettling for several reasons. Initially, allowing employers to refuse to accommodate plaintiffs who select medical interventions later deemed to be "unnecessary" or "inappropriate" is inconsistent with the broad conceptualization of a disabling correction that is advocated in this Note. Moreover, as long as an employer feels confident in its ability to elicit expert testimony that a disabling correction was not necessary or appropriate, it can discriminate against employees with disabilities with impunity. Such an approach undermines the autonomy of individuals with disabilities and prevents individuals who have taken significant steps to mitigate serious health conditions from participating in the economy.

Permitting employers to second-guess employees' medical decisions necessarily entails a judicial role in second-guessing these decisions as well. The Supreme Court has repeatedly cautioned lower courts against introducing judicial discretion into medical and scientific decisionmaking. ${ }^{137}$ Neither employers nor courts are especially well-

1679, 1703-06 (1999) (detailing the widespread judicial acceptance of "firm choice" requirements, wherein employers require alcoholic employees to attend a recommended treatment program or face discipline or dismissal).

135. See id. at 1697-706 (explaining the unique status of alcoholics under the ADA and the limited nature of the protections that many alcoholics receive under the Act).

136. For example, in Lent v. Goldman Sachs \& Co., No. 97 Civ. 9413, 1998 U.S. Dist. LEXIS 20371 (S.D.N.Y. Dec. 29, 1998), the plaintiff's employer readily admitted that the plaintiff was terminated because his supervisors perceived him to have "poor judgment" about treating his epilepsy and because the employer (incorrectly) believed that he had a "cavalier" attitude about taking his anti-seizure medication. Id. at *8. Similarly, in Finical v. Collection Unlimited, 65 F. Supp. 2d 1032 (D. Ariz. 1999), the defendant requested that summary judgment be granted on the grounds that the plaintiff was not an individual with a disability within the meaning of the ADA. Though the plaintiff had a hearing impairment that caused her to "miss" about $37 \%$ of normal speech, see id. at 1041 , her employer argued that she was not an individual with a disability because, in the employer's view, she should have been using a hearing aid to mitigate the effects of her condition, see $i d$. at 1037. Though the defendants in both of these cases were denied summary judgment, these cases evidence a willingness on the part of employers to attempt to question and interfere with their employees' (and their employees' physicians') medical judgments about how most appropriately to treat impairments.

137. See, e.g., Marshall v. United States, 414 U.S. 417, 427 (1974) (“When Congress undertakes to act in areas fraught with medical and scientific uncertainties, legislative options 
qualified to determine whether elective medical treatments are either "necessary" or "appropriate." 138 It makes little sense to burden the courts with highly technical factual disputes (frequently turning on expensive and time-consuming expert testimony) when the employee already has every incentive to avoid the expense and risk of medical interventions that are truly unnecessary or inappropriate.

Beyond the burden on the courts that such "necessity challenges" to disabling treatments would entail, the increased employer involvement in private medical decisionmaking that results from these challenges also presents a number of significant problems. Such involvement runs counter to the ADA's explicit policy goal of enhancing the independence and autonomy of individuals with disabilities. ${ }^{139} \mathrm{~A}$ judicial approach to correctable disabilities that effectively allows employers to dictate the outcome of medical decisions necessarily reduces the range of treatment options (and the range of employment options) available to the individuals with disabilities. Moreover, in the context of controversial or experimental corrections, extensive employer involvement in treatment decisions could adversely affect an employee's health. For example, an individual who had a choice between a riskier treatment (perhaps a surgical treatment) that, if effective, would have fewer side effects requiring workplace accommodation, and a less risky treatment (perhaps a medical, drug-based treatment) with more side effects requiring workplace accommodation might effectively be forced to choose a treatment option that endangered his or her health more in order to endanger his or her job less. Finally, constitutional privacy and liberty interests may be implicated when a governmental employer attempts to use the terms and conditions of employment to interfere with an individual's autonomy in medical decisionmaking. ${ }^{140}$

must be especially broad and courts should be cautious not to rewrite legislation, even assuming. arguendo, that judges with more direct exposure to the problem might make wiser choices.").

138. See Ethyl Corp. v. EPA, 541 F.2d 1, 67 (D.C. Cir. 1976) (Bazelon. J., concuning) (" [S]ubstantive review of mathematical and scientific evidence by technically illiterate judges is dangerously unreliable ...."); Scott Brewer. Scientific Expert Testimony and Intellectual Due Process, 107 YALE L.J. 1535, 1539 (1998) ("'N]onexper judges' and juries' lack of understanding of the cognitive aims and methods of science and their reliance on such indicia of expertise as credentials, reputation, and demeanor to choose between competing scientific experts thus yield only epistemically arbitrary judgments.").

139. See 42 U.S.C. \& 12101(a)(8) (1994).

140. Most courts, however, have not considered such interests controlling. at least when considering whether an employee has the right to refuse employer-mandated treatment for alcoholism. In such instances, employees have been more successful contesting the constitutionality of compelled treatments under state constitutions. See Edwards, supra note 134. at 1724-30. 


\section{REGULATORY REFORM}

As described above, the provisions of the EEOC's Title I regulations emphasizing the duration and long-term impact of an impairment have facilitated the prevailing judicial reluctance to accept corrective measures as disabilities. Though the previously quoted regulations specify that "duration" and "long-term impact" are two of the three factors involved in a determination of disability, the first and undoubtedly most important factor is the nature and severity of the impairment. Because the courts frequently read the regulations to preclude the classification of temporary conditions as disabilities, ${ }^{141}$ an amendment to those regulations could encourage courts to give the disabling corrections corollary the expansive scope that the statute and the Supreme Court's Sutton opinion necessitate.

The EEOC's Title I regulations should include a caveat indicating that the last two factors in the substantial impairment test (duration and longterm impact) should be less determinative when the impairment in question is a side effect of an attempt to mitigate another underlying condition. For example, a new subsection (iv) could be added to 29 C.F.R. $\S 1630.2(j)(2)$ reading as follows: "When the impairment in question results from the side effects of a treatment or corrective measure, consideration of the duration and long-term impact of the impairment should not necessarily preclude the classification of such impairments as disabilities."

In essence, the severity factor would be permitted to trump the duration and long-term impact requirements when the impairment under consideration is the side effect of an attempt to remedy an underlying condition. This change would be consistent with the goals of the ADA, encouraging individuals to mitigate the effects of underlying conditions in order to participate in the economy. Moreover, such regulatory language would allow for an adequately broad interpretation of the disabling corrections corollary that would appropriately target the narrowing effects of the correctable disabilities decisions.

There is some indication that the EEOC would favor such a change. Despite its regulatory language, the agency has never maintained that permanency should be a per se requirement for establishing a disability under the ADA. ${ }^{142}$ Moreover, the EEOC's amicus curiae brief in Sutton reveals the agency's preference for a broad construction of the ADA's applicability. ${ }^{143}$ Perhaps most significantly, in her public comments following the release of the Sutton opinion, EEOC chairwoman Ida Castro indicated that Sutton's reference to disabling corrections was in accord with

141. See, e.g., Burch v. Coca-Cola Co., 119 F.3d 305, 316 (5th Cir. 1997) (arguing that "permanency ... is the touchstone of a substantially limiting impairment").

142. See, e.g., Burgdorf, supra note 103, at 479.

143. See EEOC amicus brief, supra note 42 , at 7-9. 
the Commission's position that "people who use mitigating measures may still be substantially limited in major life activities and thus may enjoy the protection of the ADA." 144

The efficacy of a strategy that focuses on changes to the definitional portions of the EEOC regulations may be somewhat doubtful in light of the language in Sutton questioning the deference due those regulations ${ }^{145}$ and the apparent "judicial uprising" against the EEOC's ADA regulations. ${ }^{146}$ In the correctable disabilities cases, however, the Supreme Court declined to rule on the degree of deference owed to the EEOC's interpretation of the term "disability." 147 The Court disregarded the interpretive guideline requiring that an impairment be considered in an uncorrected state without regard to mitigating measures because the Court concluded that this guideline conflicted with the plain language of the statute. The few courts that have had the opportunity to examine the continued validity of the EEOC's other definitional regulations after Sutton have continued to find these regulations instructive. ${ }^{148}$

The regulatory change proposed here is consistent with the plain language of the ADA; it would merely deemphasize two of three previously articulated factors in the regulatory definition of a "substantial limitation" when the impairment in question is a disabling correction. In the absence of direct statutory conflict, there are strong arguments in favor of continued deference to the EEOC's regulations. ${ }^{149}$ Moreover, the Sutton majority's reference to the regulatory definition of "substantially limits" in explaining

144. EEOC Chairwoman Comments on ADA Rulings by Supreme Court During Speech to Plaintiffs Bar in New Orleans (last modified July 1, 1999) <http:/www.ceoc.gov/press/7-199.html >.

145. See Sutton v. United Air Lines, 119 S. C. 2139, 2145-47 (1999).

146. See, e.g., Colker, supra note 73, at 102, 135-36; Locke, supra note 30, at 113-15.

147. See Sutton, 119 S. Ct. at 2145-46.

148. Most such courts have noted the language in the Sutton opinion addressing the need for deference to the EEOC's regulations, but this language has been interpreted in highly divergent fashions. While one Arizona district court said that the Court in Stuton "assumed. without deciding," that the regulations were reasonable. Finical v. Collections Unlimitcd. 65 F. Supp. $2 d$ 1032, 1042 (D. Ariz. 1999), the Fifth Circuit characterized the Sutton language as "cast[ing] a shadow of doubt over the validity and authority of the EEOC's regulations." EEOC v. RJ. Gallagher Co., 181 F.3d 645, 654 n.5 (5th Cir. 1999) (declining to address the question of the continued applicability of the EEOC regulations). Regardless of cach particular court's "slant" on the Sutton language, most post-Sutton opinions considering the need for deference to the EEOC's regulations implementing the generally applicable provisions of the ADA have continued to defer to the EEOC's regulations on the grounds that such deference is " the law of the circuit" until and unless the Supreme Court issues a more definite statement indicating otherwise. See, e.g., Muller v. Costello, 187 F.3d 298, 313 n.5 (2d Cir. 1999); Finical. 65 F. Supp. 2d at 1042: Tatum v. Hospital of the Univ. of Pa., No. 98-6198, 1999 U.S. Dist. LEXIS 10174, at *10-11 (E.D. Pa. June 24, 1999); cf. Muszak v. Sears, Roebuck \& Co., 63 F. Supp. 2d 292, 299 (W.D.N.Y. 1999) (using the EEOC's three-factor test to determine what constitutes a substantial limitation on a major life activity post-Sutton). Similarly, there is some indication that practitioners plan to continue to rely on EEOC guidelines. See, e.g., Panel Discusses Impact of Supreme Cour Decisions, DISABILTY COMPLIANCE BULL. (LRP Publications, Alexandria, VA), Aug. 30, 1999.

149. See, e.g., Colker, supra note 73 , at 134-37. 
why the plaintiffs did not meet the "regarded as" prong of the statutory definition of disability provides further evidence of the continued persuasive effect of the EEOC's regulations. ${ }^{150}$

The EEOC's amended Title I regulations should discourage the courts from placing undue emphasis on the "duration" and "long-term impact" factors when evaluating whether a corrective measure substantially limits a major life activity. Such a regulatory change would clearly indicate to employers and the courts that the agency supports a generous interpretation of the Sutton decision that will continue to protect those individuals who have gone to great lengths to mitigate disabling impairments and who are willing to endure the side effects of disabling corrections in their attempt to remain self-sufficient participants in the national economy.

\section{A REVISED JUDICIAL APPROACH}

If the disabling corrections corollary is to play an effective role in reconciling the ADA's promise of autonomy and opportunity for individuals with disabilities with the Supreme Court's concern for limiting frivolous litigation, the courts must adopt both a broad conceptualization of disabling corrections and an appropriately deferential approach toward reviewing employees' choices of corrective treatments or technologies. Judicial deference is not something that can easily be dictated by a regulation or even a statute. It is an attitude that reflects sensitivity to the role that Congress has assigned to the courts as enforcers of the ADA and an appreciation for the policies that Congress meant for the statute to effectuate.

\section{A. A Broad View of Disabling Corrections}

Initially, in marked contrast to their pre-Sutton approach (in which courts seemed disinclined to accept even severe side effects of corrective measures as disabilities), post-Sutton courts should be especially hesitant to conclude that the significant side effects of a treatment are not appropriately considered disabling. Critical to this generous judicial interpretation of the disabling corrections corollary is the need to view the effects of treatments holistically.

In light of the Sutton decision, courts called upon to determine whether an individual meets the ADA definition of disability will no longer evaluate the individual's underlying condition. Instead, these courts will scrutinize the degree of success with which the individual is mitigating his or her underlying impairment. With this change will come an inevitable increase 
in the number of claims of disability that are based on the side effects of corrective measures. In evaluating such side effects, it is important to recognize that treatments such as drug therapies often produce multiple side effects that can vary according to the dosage of the drug and the stage of the treatment. ${ }^{151}$ These multiple side effects can have synergistic effects, especially when an individual is taking many types of medication simultaneously. For example, the nausea induced by one medicine can exacerbate the weakness and fatigue caused by another. Similarly, an individual who experiences mild dizziness, mild nausea, moderate tremors, and mild depression as side effects of a drug might experience a significant impairment that results not from any individual side effect, but instead from the debilitating impact of this combination of otherwise minor impairments.

An appropriately broad reading of Sutton's "disabling corrections" language requires courts to acknowledge the cumulative impact of numerous side effects on an individual's ability to engage in major life activities. Indeed, for a patient who uses multiple drug therapies, the cumulative effect of many independently minor side effects can be far more debilitating than the severity of the individual effects might indicate. Courts should readily acknowledge that the "whole" side effect of a drug therapy program can often be greater than the sum of its parts. Adopting such a holistic approach when evaluating the impact of multiple minor impairments would not be a novel judicial strategy. A number of federal courts have already acknowledged the validity of such an approach in the context of both ADA and Social Security disability claims. ${ }^{152}$ For example, in Reichenbach v. Heckler, ${ }^{153}$ a Social Security disability case, the Fourth Circuit overruled an administrative law judge's finding that an individual with Reiter's syndrome was not entitled to Social Security disability benefits. Though Reichenbach's evaluating physician maintained that the symptoms that he was experiencing as a result of his underlying condition were not sufficient to qualify him for disability benefits, Reichenbach was also experiencing psychological problems that were independent of the effects of the Reiter's syndrome. ${ }^{154}$ The Fourth Circuit chastised the administrative law judge for failing to analyze the cumulative, or synergistic, effect of the claimant's various impairments, and ruled that an

151. See supra Section II.B.

152. See, e.g., Hines v. Bowen, 872 F.2d 56. 59 (4th Cir. 1989) (per curiam) (finding. in the Social Security disability context, that the synergistic effect of several minor conditions may result in major disability); cf. United States v. Henley, 8 F. Supp. 2d 503 (E.D.N.C. 1998) (evaluating the mental health of a prisoner due for release). In Henley, the court evaluated "not only the severity of Respondent's disorders, but the interaction of the disorders and their combined effect on Respondent." Id. at 507. The cour found that the "synergistic effect of the two disorders results in a substantial impaiment of Respondent's ability to function in socicty and to control his behavior." Id.

153. 808 F.2d 309 (4th Cir. 1985).

154. See id. at 310 . 
effective consideration of "the residual functional capacity of the individual... requires a combined analysis of all physical and mental impairments." 155

Such analysis is applicable in the context of ADA claims as well. For example, in Creswell v. Deere, ${ }^{156}$ a Texas district court declined to grant summary judgment on the defendant employer's claim that a former employee was not an individual with a disability within the meaning of the ADA. Though the employer argued that neither the effects of the plaintiff's diabetes nor the effects of the plaintiff's asthma were severe enough to limit substantially a major life activity, the court opined that "[a]ll of the cases cited by Defendant ... only consider one of the two conditions (diabetes or asthma), not the effect of both of these ailments (diabetes and asthma) on major life activities." 157 The court agreed with the plaintiff that "the better approach in this case is to view the cumulative effect of Plaintiff's conditions on her major life activities." ${ }^{158}$ The need for courts to engage in such synergistic evaluations is even more pressing when these courts are considering the impact of potentially disabling corrections like drug therapies, which tend to have a number of significant (but not necessarily severe) side effects. Moreover, this permissive view of disabling corrections is more consistent with both the pro-work policies underlying the ADA and the pro-mitigation goals of the Sutton majority than an approach that would deny the ADA's protections to those who endure debilitating side effects in order to mitigate an even more restrictive underlying condition.

\section{B. Judicial Deference to Employee Decisions}

The suggestion in Sutton that disabling corrections are still actionable under the ADA will no doubt encourage employers to second-guess the choices that employees make to mitigate disabling conditions. There is some indication in the pre-Sutton cases of a judicial willingness to allow employers to inquire into both the "necessity" and "acceptability" of disabling medical treatments. Requiring an ADA plaintiff to justify the necessity or appropriateness of a decision to mitigate the effects of a health problem is inconsistent with a broad application of Sutton's "disabling corrections" language.

The courts should be especially wary of the very real potential that an unduly narrow application of the disabling corrections corollary will involve employers and the judiciary in the technically complex and highly

155. Id. at 312 .

156. No. 3:96-CV-1392-P, 1997 U.S. Dist. LEXIS 22890 (N.D. Tex. Oct. 21, 1997).

157. Id. at *24 (emphasis omitted).

158. Id. 
personal business of evaluating the appropriateness of medical interventions. Such second-guessing also encourages employers and the courts to inquire into what an individual's limitations might be under a hypothetical alternate treatment program. The Sutton majority specifically argued against the use of such hypothetical inquiries. ${ }^{159}$ Most alarmingly, judicial willingness to entertain employers' attempts to second-guess employees' medical choices may encourage employers to force employees to select alternative treatments that are less expensive to accommodate but more dangerous or disruptive to the plaintiff.

To reduce the potential for such second-guessing, the courts should establish a strong presumption in favor of an individual's informed choice of corrective treatments in deciding whether he or she is an individual with a disability within the meaning of the ADA. ${ }^{160}$ Such a presumption would preserve scarce judicial resources by discouraging questionable employer strategies of the sort employed by the defendant in Berk v. Bates Advertising USA, ${ }^{161}$ aimed at creating medical controversies where none exists in order to challenge the appropriateness of the advice of the plaintiff's treating physician. A strong judicial presumption in favor of an individual employee's informed medical judgement would also minimize the risk of undesirable employer influence over private health care decisions. Finally, such a presumption would go a long way toward ensuring the vitality of the disabling corrections corollary to the correctable disability rule.

Precedent exists for erecting a presumption in favor of the judgment of an individual and that individual's treating physician in other fields of health law. For example, in administering the Early and Periodic Screening, Diagnosis and Treatment (EPSDT) Program (a program that provides medically necessary health care services to Medicaid-eligible children under age twenty-one), ${ }^{162}$ state Medicaid agencies must give a strong presumption of deference to the treating physician's assessment of medical necessity. ${ }^{163}$ State agencies, of course, may rebut the presumption, although

159. See Sutton, 119 S. Ct. at 2147.

160. Clearly, this presumption of deference would also apply when the medical choice that an employer is second-guessing is a decision to refuse treatment for an underlying condition rather than a choice to utilize a disabling correction. Indeed, these situations are of an essentially similar nature, given that the former decision (to refuse treatment) is generally made in order to avoid disabling side effects. The fundamental choice at issue (whether or not to utilize a disabling correction) is the same. The potential dangers of permitting courts or employers to question the acceptability of the decision are the same in both contexts, and the need for a presumption of deference is as strong. The only exception to this premise might be the decision to refuse substance-abuse treatment, where the applicable law is somewhat uniquc. See supra note 135.

161. See supra text accompanying notes 119-125.

162. See 42 U.S.C. $\$ 1396$ d(r) (1994).

163. As the Eight Circuit held in Pinneke v. Preisser, 623 F.2d 546 (8th Cir. 1980). "The decision of whether or not certain treatment or a particular type of surgery is imedically 
the courts have not articulated definitive rebuttal criteria. The Fifth Circuit adopted a typical test in Ruch v. Parham, ${ }^{164}$ when it suggested that a state could overrule a treating physician's judgment regarding the medical necessity of a particular procedure or treatment, based on reasonable standards, when the procedure in question was "experimental" or did not constitute a "medically appropriate" treatment. ${ }^{165}$

Because incentives in the ADA and Medicaid contexts are notably dissimilar, different rebuttal criteria are required. States administering the EPSDT program are legitimately concerned that individuals may attempt to "game the system" or "doctor-shop" to secure assistance for inessential but nonetheless desirable treatments. This incentive structure may justify less deference to physician-assisted medical choices in an EPSDT case than is warranted in a disabling corrections case, where employees have less incentive to doctor-shop for a physician willing to recommend a treatment option that is unnecessarily disabling in order to receive accommodations in the workplace.

It is important to emphasize that courts should not allow employers to rebut informed employee choices of corrective procedures or technologies on the grounds that the employee's choice posed too great a risk to the employee's own physical or mental well-being. Although the potential for moral hazard is always present in social interactions in which costs can be shifted from one person to another, it is highly unlikely that an employee would undergo a risky treatment or corrective technique solely to take advantage of his or her employer's obligation to accommodate under the ADA.

This is not to say that the presumption in favor of an individual's informed treatment decisions that is advocated here should be irrebuttable. The potential problem being targeted in this instance is not the unnecessary utilization of a state's medical resources (as in the EPSDT example), but instead the relatively rare instance of the individual who has a truly "voluntary disability," either because the individual has refused treatment for the condition or-less likely-because the individual has elected an unnecessarily disabling treatment option. ${ }^{166}$ Thus any limits on the

necessary' rests with the individual recipient's physician and not with clerical personnel or government officials." Id. at 550 .

164. 625 F.2d 1150 (5th Cir. 1980).

165. See id. at 1152 .

166. Disabling corrections may be a subset of a broader class of what Professor Lisa Key of the University of Missouri-Columbia refers to as "voluntary disabilities." Professor Key suggests that the appropriate way for courts to treat a voluntary disability is to address the extent to which the impairment is voluntary when determining the existence of a disability and when determining the reasonableness of accommodations. See Lisa E. Key, Voluntary Disabilities and the ADA: A Reasonable Interpretation of "Reasonable Accommodations," 48 HASTINGS L.J. 75, 97 (1996). Permitting employers to question the necessity of a disabling treatment (or the advisability of refusing a disabling treatment) at both stages in the litigation would exacerbate the "pre-approval 
presumption of deference should be geared to address this problem. Perhaps the clearest case in which the presumption is appropriately rebutted is that of the "uninformed" employee. If an employee has chosen a correction without expert advice or over the objections of an expert advisor, the likelihood that the employee is attempting to game the system is higher. It is also more likely that such uninformed choices are made to advance trivial interests that do not warrant the ADA's protection. The ADA's concern for employee autonomy is still relevant, however, even if the employee elects to proceed without expert advice. Courts should therefore allow employers to rebut the presumption of deference to employee decisions by demonstrating that the employee chose a disabling correction for a preexisting disability without the advice of or over the objection of a treating physician or other relevant expert. ${ }^{167}$ The court would then entertain an inquiry into the necessity or appropriateness of the correction with the aid of any relevant expert testimony that the defendant and the plaintiff wish to present. ${ }^{168}$

Undoubtedly, there are other situations in which an employer may appropriately rebut the presumption of deference to the judgment of an individual and his or her treating physician. It is not the goal of this Note to provide an exhaustive list of such situations. Moreover, it is admittedly one of the flaws of the presumption-of-deference approach that evidentiary standards will often constrain an employer's opportunity to rebut this presumption. ${ }^{169}$ However, when an individual's ability to make personal

effect" described above and would increase the extent to which the employer could impose upon an employee's treatment decisions.

167. Admittedly, the cases involving truly "uninformed" employees would be exccedingly rare, as most treatments that would have side effects significant enough to be considered disabling (such as a prescription drug therapy or surgical treatment) would require physician approval. Thus, this caveat would more frequently be utilized in the context of those employces who refuse to employ mitigating measures prescribed by their physicians. For example, employers would be permitted to question legitimately whether they are obligated to accommodate those individuals who refuse to take prescribed medications. See, e.g., Bowers v. Multimedia Cablevision, Inc., No. CIV.A. 96-1298-JTM, 1998 WL 856074, at *4 (D. Kan. Nov. 3, 1998) (ruling that a "plaintiff cannot gain ADA protection by unilaterally deciding, without justification, not to use prescribed medication which corrects or alleviates his condition").

168. This approach to identifying voluntary disabilities necessarily gives great weight to the opinion and expertise of the treating physician. There are, of course, problems inherent in placing such emphasis on a medical professional's "validation" of impairments as a precondition to a finding of disability. See Crossley, supra note 24, at $689-96$ (critically assessing the "medical model" of disability).

169. For example, it seems logical that an employer should be able to rebut the presumption of deference by demonstrating that an employee has selected a corrective procedure or technology solely for trivial cosmetic or recreational reasons unrelated to the overall health and well-being of the employee. However, given that this rebuttal criterion has the potential to involve the courts in probing deeply personal thought processes of employees, the most applicable evidence is likely to be conversations that are subject to the doctor-patient privilege. Though it might othervise be appropriate to permit an employer to prove that an employee had trivial reasons for choosing a particular correction, the courts should not waive any evidentiary privileges to allow employers to probe employee motivations. 
health decisions independent of any influence by his or her employer is at stake, it seems appropriate to err on the side of protecting the employee's autonomy. The courts should take care not to allow the rebuttal criteria to multiply to the point at which the presumption is easily rebutted. Though this "strong-presumption" approach may give rise to the occasional situation in which an employer must accommodate the limitations of an individual whose doctor has approved an unnecessarily disabling treatment, such instances will undoubtedly be rare. As detailed above, there is no incentive for an individual to choose an unnecessarily disabling treatment in order to receive workplace accommodations. Therefore, there are very few compelling reasons to allow an employer with limited medical expertise to challenge the medical judgements of a knowledgeable employee and his or her physician. Moreover, even a minimal regard for the autonomy of individuals with disabilities demands that employers and the courts respect an individual's personal medical decisions about treatment options.

Only by retaining a strong presumption in favor of employees' decisions can the courts ensure that an employee who makes the difficult decision to use a disabling correction in order to remain in the workplace will not be discouraged by the threat of discrimination. Moreover, such a presumption of deference would also help to ensure that individuals such as the plaintiff in Berk v. Bates Advertising USA, ${ }^{170}$ who, in order to remain in the workforce, undergo highly invasive treatments that will forever restrict them from engaging in major life activities, are not subjected to the humiliating prospect of having to justify to their employers' satisfaction why the difficult medical decisions that they made were in fact "acceptable." Finally, a strong presumption that can be rebutted only in the most egregious cases maintains the broad disabling corrections corollary to the correctable disabilities rule and also strikes a proper balance between the ADA's concern for enhancing the employment opportunities of individuals with disabilities and the Supreme Court's concern for limiting trivial claims on judicial resources.

\section{CONCLUSION}

The Supreme Court's decisions in the correctable disabilities cases provoked significant popular controversy because the majority opinions seemed to call into question commonly held beliefs about the scope and power of the ADA. It is still unclear what the precise legal effect of these decisions will be. Both the EEOC's reaction to these decisions and the first lower-court interpretations will be critical in determining the impact that the Sutton line of cases will have on the protections available to individuals

170. 25 F. Supp. $2 d 265$ (S.D.N.Y. 1998). 
with disabilities in the workplace. If the EEOC and the lower courts adopt the interpretation of Sutton espoused by many in the popular media and concede that the ADA's workplace protections have been effectively gutted, the impact on individuals with disabilities will likely be so severe as to necessitate a complete reworking of the statute by Congress. A less sweeping interpretation of the majority's holding in these cases could avoid such a drastic outcome by targeting the decisions to affect only those individuals with impairments that are relatively trivial and can be easily and completely corrected.

If lower courts read Sutton carefully and espouse a moderate interpretation of the decision, the Supreme Court's holding will not spell the end of Title I's workplace protections for individuals with disabilities. Indeed, this opinion can and should be read to articulate a powerful and consistent vision of the ADA, instructing courts and employers to "take people as they are" when evaluating employees' eligibility for the ADA's protections. Critical to this moderate interpretation of the correctable disabilities cases is a broad reading of the majority's apparently calculated restriction on the reach of its own holding to exclude disabling corrections. Just as lower courts should "take people as they are" when evaluating myopic individuals who use glasses to correct their visual impairments, these courts must also take people as they are when evaluating epileptic individuals who are experiencing short-term side effects while adjusting to a new regimen of medications.

This permissive interpretation of the "disabling corrections" language in Sutton is necessary to ensure that the large number of individuais who must use treatments with significant side effects in order to correct their underlying impairments remain protected by the ADA. Excluding individuals who utilize such disabling corrections from the ADA's protections is inconsistent with the pro-work, pro-mitigation policy goals underlying both the ADA and the Sutton opinion. It violates both our national interests and our most basic notions of fairness to permit workplace discrimination against individuals who endure severe and disabling side effects in order to remain self-sufficient participants in the national economy. 
